\title{
SILVER IN URBAN WASTEWATER
}

\author{
Jennie Amneklev \\ Department of Biology and Environmental Science, \\ Linnaeus University, Kalmar, \\ Sweden
}

\begin{abstract}
As the use of consumer products is increasing, a similar increase of hazardous substances can be seen in sewage sludge in Swedish wastewater treatment plants (WWTPs). Silver (Ag) is a heavy metal with a high accumulation rate in soils when applying sewage sludge as fertilizer on arable land. Silver is therefore prioritized in REVAQ, a certificate system for Swedish WWTPs. The levels of Ag in the incoming water to the WWTP are today too high and must be reduced. This study aims to identify major diffuse emission sources of Ag and map out the inflow to, the stock (accumulated amount in the technosphere) and the outflow from Stockholm during 2012. In 2012, $62 \mathrm{~kg}$ silver was measured in the sludge in Henriksdal WWTP in Stockholm. Sources explaining $56 \%$ of the measured amount of silver have been identified in this study, corresponding to $46 \mathrm{mg}$ Ag per person and year. The sources with the largest contribution of silver are estimated to be textiles (19\%), urine and faeces (from for example amalgam fillings and food) (15\%) as well as cleaning products (7\%). The inflow of Ag to Stockholm during 2012 was estimated to $3200 \mathrm{~kg}$ and the stock to 105 tons, where electric goods and appliances as well as silverware and jewellery together explain $94 \%$ of the inflow and $98 \%$ of the stock.
\end{abstract}

\section{KEYWORDS}

Sewage sludge, silver, substance flow analysis, wastewater

\section{INTRODUCTION}

Emissions of chemicals from the societies have over the recent decades changed in several different ways, as both the number and amount of different substances have increased dramatically, particularly in consumer goods that we use every day. The sources have also changed from being well-defined industrial emissions to diffuse emissions from, for example, the mentioned products we surround ourselves with. The trend towards more diffuse sources has meant that it is difficult to get an overall picture of where the emissions occur. A large portion of emissions from diffuse sources end up in our wastewater treatment plants, which can result in high levels of unwanted substances in the sewage sludge. This sludge, due to its high nutrient inside-hold, is profitable used as a resource and returned to our arable lands, which is difficult if it contains unwanted substances. When adding sewage sludge as a fertilizer on arable land, an important factor to consider is the accumulation rate. Silver (Ag) 
is one of the heavy metals with the highest accumulation rate when added to soil (REVAQ, 2013).

Silver occurs in consumer products in nano, ionic, colloidal and elemental form (Thomas, 2009). The Ag ion is one of the most toxic forms of heavy metal (surpassed only by mercury) (Purcell and Peters, 1997) and nano Ag has shown to be toxic to a variety of aquatic organisms, including fish (Bilberg et al., 2010, Scown et al., 2010, Zimmerman et al., 2002), while metallic Ag is not as toxic (Purcell and Peters, 1997). The metal has long been used as medicine or dietary supplement and the most common health effect of a prolonged exposure is Argyria or Argyrosis (Drake and Hazelwood, 2005), where the skin or eye pigments are affected and given a grey or blue shade. At higher doses, Ag accumulates in the skin, liver, kidney, corneal rails, gums, mucous membranes, nails, and spleen.

The aim with this study was to quantify the sources of silver affecting incoming wastewater to a wastewater treatment plant (WWTP). This is done by conducting a substance flow analysis where the inflow, stock and outflow of silver are calculated for an urban area.

\section{METHOD}

Substance flow analysis (SFA) is a method commonly used to map the flows and stocks of different substances in, for example, an urban area (van der Voet et al., 1995). Stock means the stored amount of a substance that can exist in a society. For a successful SFA, three steps have to be taken (Udo de Haes et al., 1997): (1) the spatial and temporal boundaries have to be defined; (2) the inflows, stocks and outflows have to be quantified for the substance of interest and; (3) the results have to be interpreted.

For this study, the capital of Sweden, Stockholm, was chosen as a study area and the outflow was limited to flows to the urban wastewater system. During 2012, the year chosen for this study, approximately 750000 persons were connected to the reception area of Henriksdal WWTP, the dominant WWTP in Stockhom. The composition of the incoming water to this treatment plant is expected to be representative for many urban areas. During 2012, $62 \mathrm{~kg} \mathrm{Ag}$ was measured in Henriksdal WWTP and today the sewage sludge from Henriksdal is used as landfill cover in northern Sweden.

\section{RESULTS AND DISCUSSION}

This SFA has focused on sources of Ag that affect the measured Ag concentrations in sewage sludge in Henriksdal WWTP. The results and calculations are based on Amneklev et al. (2014b).

Inflow and stock

The total Ag inflow to Stockholm during 2012 was estimated to 1.6 tonnes/year (Figure 1) and the total stock to 45 tonnes (Figure 2) (Amneklev et al., 2014b). Jewellery and silverware is the source explaining the majority of the inflow and stock. 


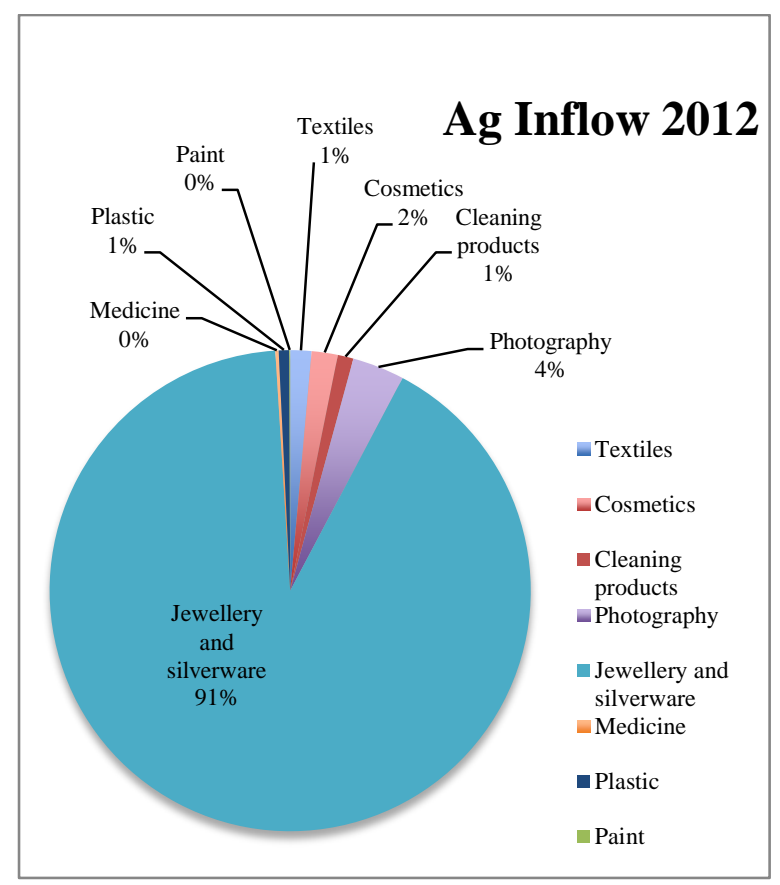

Figure 1. Different sources explaining the Ag inflow to Stockholm (\%/year). Total amount: 1.6 tonnes. Source: Amneklev et al., 2014

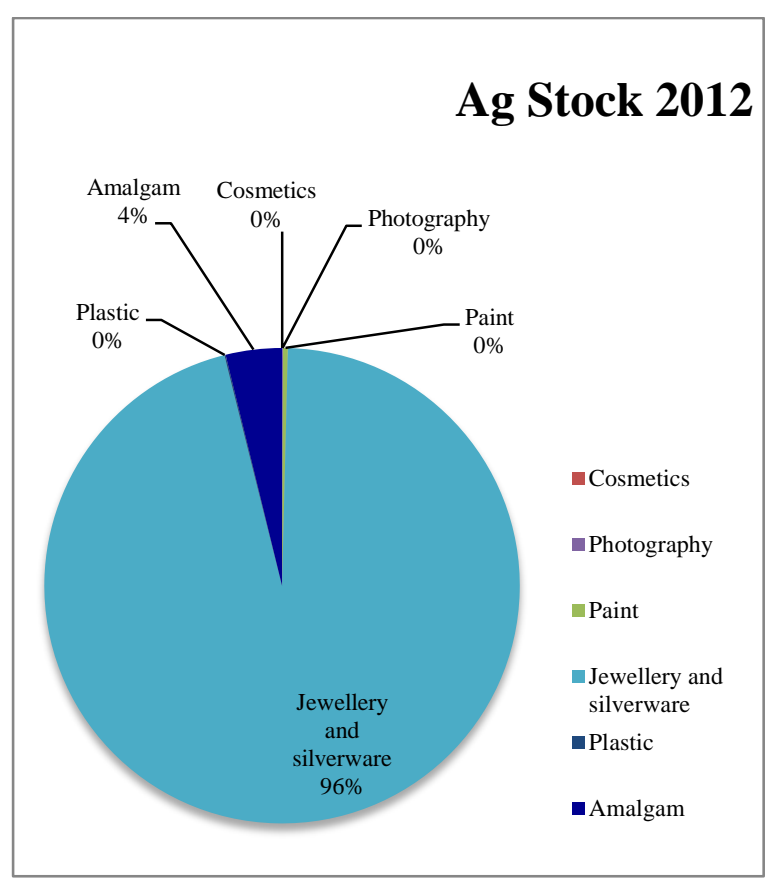

Figure 2. Different sources explaining the Ag stock of Stockholm (\%). Total amount: 45 tonnes. Source: Amneklev et al., 2014

For products that do not provide an outflow affecting the WWTP (see below) has neither had their inflow or stock examined.

\section{Outflow}

Estimated amounts of silver (kg/year) from different sources of Henriksdal WWTP are presented in Table 1. The table also shows the proportion the respectively source has of the total measured Ag in Henriksdal WWTP during 2012 (62 kg) what amounts this equivalent per person. Larger sources in the household are identified to be textiles, urine and faeces (including amalgam, food and other consumer products), while it for businesses is vehicles and public health care.

Table 1. Different sources explaining the Ag outflow from Stockholm (in incoming water to Henriksdal WWTP) Source: Amneklev et al., 2014b

\begin{tabular}{|c|c|c|c|}
\hline Source & $\begin{array}{l}\text { Mean value }{ }^{1} \text { (kg } \\
\text { Ag/year) }\end{array}$ & $\begin{array}{l}\text { Proportion }^{2} \\
(\%)\end{array}$ & $\begin{array}{l}\text { Per person } \\
\text { (mg Ag/year) }\end{array}$ \\
\hline \multicolumn{4}{|l|}{ Households } \\
\hline Textiles & 12 & 19 & 15 \\
\hline Urine and faeces & 9.2 & 15 & 12 \\
\hline whereof amalgam & 3.7 & 6 & 4.9 \\
\hline whereof food and other ${ }^{4}$ & 5.5 & 8.9 & 7.2 \\
\hline Cleaning products & 4.1 & 6.6 & 5.3 \\
\hline Photography & $<0.1$ & 0.1 & 0.1 \\
\hline Paint & 0.5 & 0.8 & 0.7 \\
\hline Jewellery and silverware & 0.3 & 0.5 & 0.4 \\
\hline Plastic & 0.3 & 0.5 & 0.4 \\
\hline Cosmetics $^{5}$ & $<0.1$ & $<0.1$ & $<0.1$ \\
\hline Amalgam (brushing) & $<0.1$ & $<0.1$ & $<0.1$ \\
\hline Hygiene products $^{6}$ & - & - & - \\
\hline \multicolumn{4}{|l|}{ Businesses } \\
\hline Vehicles (washes) & 1.6 & 2.6 & 2.1 \\
\hline Public health care $^{7}$ & 3.5 & 5.6 & 4.6 \\
\hline
\end{tabular}


Linnaeus ECO-TECH '14,

Kalmar, Sweden, November 24-26, 2014

\begin{tabular}{llll} 
Dentists & 0.4 & 0.7 & 0.6 \\
Photo labs & 0.2 & 0.2 & 0.3 \\
Laundries & $<0.1$ & $<0.1$ & $<0.1$ \\
\hline Other & & & \\
Storm water & 0.5 & 0.8 & 0.7 \\
Drinking water & 0.3 & 0.5 & 0.4 \\
Leakage and drainage water & 0.3 & 0.5 & 0.4 \\
Flocculent & 2 & 3.2 & 2.6 \\
Sedimentation in pipes & - & - & - \\
\hline Total & $\mathbf{3 5}$ & $\mathbf{4 6}$ \\
Total measured amount & $\mathbf{6 2}$ & \\
\hline${ }^{1}$ For calculated mean value, see Supplementary & \\
${ }^{2} \%$ of total measured sewage sludge in Henriksdal WWTP during 2012 \\
${ }^{3}$ 767 650 citizens were connected to Henriksdal WWTP during 2012 \\
${ }^{4}$ Calculated based on what is left in urine and faeces when the amount for amalgam has been extracted. Other \\
includes hygiene products, cosmetics and skin products absorbed by the skin \\
5 Includes foundation, powder and eye shadow (Amneklev et al., 2014a) \\
${ }^{6}$ Hygiene products include for example soap and skin lotion \\
${ }^{7}$ Including X-rays \\
${ }^{8}$ Amount measured in sewage sludge in Henriksdal WWTP during 2012 \\
- Potential source but support for calculations are lacking
\end{tabular}

Strategies to reduce silver going to the wastewater were investigated for sources with a contribution corresponding to over $5 \%$ of the total measured amount (Amneklev et al., 2014b). This includes textiles, urine and faeces (both amalgam and food / skin products), cleaning products and public health care facilities. For all these sources, relevant legislation is missing in Sweden and Europe. Neither has information been found if there is legislation in other parts of the world. Textiles may be investigated further by laundries analysing their outgoing water, producers stop adding Ag to their products as well as consumers to chose not to by Ag-containing clothes. Silver in amalgam is expected to decrease since the legislation forbidding the use of amalgam was implemented in 2009. Silver may be present in food and hygiene products, but no studies have been conducted confirming this in Sweden. More studies are also needed for Ag in cleaning products and public health care facilities to examine how common the usage of $\mathrm{Ag}$ is as well as in which kind of products.

Important parties for reducing silver in wastewater are suggestively the governments, the producers, the businesses and the consumers.

\section{REFERENCES}

AMNEKLEV, J., AUGUSTSSON, A., SÖRME, L. \& BERGBÄCK, B. 2014a. Bismuth and silver in cosmetic products - a source of environmental and resource concern? Journal of Industrial Ecology. In press

AMNEKLEV, J., BERGBÄCK, B., SÖRME, L., LAGERKVIST, R., KOTSCH, M. \& AUGUSTSSON, A. 2014b. Stratergies to reduce silver and bismuth in urban wastewater (In Swedish). THE SWEDISH WATER \& WASTEWATER ASSOCIATION. Stockholm.

BILBERG, K., MALTE, H., WANG, T. \& BAATRUP, E. 2010. Silver nanoparticles and silver nitrate cause respiratory stress in Eurasian perch (Perca fluviatilis). Aquatic toxicology, 96, 159-65.

DRAKE, P. L. \& HAZELWOOD, K. J. 2005. Exposure-related health effects of silver and silver compounds: a review. The Annals of occupational hygiene, 49, 575-85.

PURCELL, T. W. \& PETERS, J. J. 1997. Sources of Silver in the Environment. Environmental Toxicology and Chemistry, 17, 539.546. 
REVAQ 2013. REVAQ annual report 2012. REVAQ. Stockholm SCOWN, T. M., SANTOS, E. M., JOHNSTON, B. D., GAISER, B., BAALOUSHA, M., MITOV, S., LEAD, J. R., STONE, V., FERNANDES, T. F., JEPSON, M., VAN AERLE, R. \& TYLER, C. R. 2010. Effects of aqueous exposure to silver nanoparticles of different sizes in rainbow trout. Toxicological sciences : an official journal of the Society of Toxicology, 115, 521-34.

THOMAS, P. 2009. Behind the Label: nanosilver [Online]. Available: http://www.theecologist.org/green_green_living/behind_the_label/340403/behind_the _label_nanosilver.html [Accessed September 22 2014].

UDO DE HAES, H. A., VAN DER VOET, E. \& KLEIJN, R. Substance flow analysis (SFA), an analytical tool for integrated chain management. In: BRINGEZU, S., FISCHER-KOWALSKI, M., KLEIJN, R. \& PALM, V. (eds). Regional and National Material Flow Accounting: From Paradigm to Practice of Sustainability. Proceedings of the ConAccount Workshop 21-23 January, 1997, 1997 Leiden, The Netherlands.

VAN DER VOET, E., HEIJUNGS, R., MULDER, P., HUELE, R., KLEIJN, R. \& VAN OERS, L. 1995. Substance Flow Through the Economy and Environment of a Region. Environmental Science \& Pollution Research, 2, 137-144.

ZIMMERMAN, S., ALT, F., MESSERSCHMIDT, J., VON BOHLEN, A., TARASCHEWSKI, H. \& SURES, B. 2002. Biological availability of traffic-related platinum-group elements (Palladium, Platinum, and Rhodium) and other metals to the Zebra mussel (Dreissena Polymorpha) in water containing road dust. Environmental Toxicology and Chemistry, 20, 2713-2718. 